\title{
PROBLEM BASED LEARNING: A TOOL TO IMPROVE MARITIME SAFETY LEARNING IN THE MERCHANT MARITIME UNIVERSITY DEGREES
}

\author{
Jorge Walliser ${ }^{1}$, Bismarck Jigena ${ }^{1}$, Juan José Muñoz ${ }^{1}$, Laura Pozo ${ }^{2}$, Daniel \\ García Gómez de Barreda ${ }^{1}$ \\ ${ }^{1}$ University of Cádiz (SPAIN) \\ ${ }^{2}$ University of Sevilla (SPAIN)
}

\begin{abstract}
Since 2010, the University of Cádiz offers three new degree programs related to merchant marine officers studies. These three degrees cover the training and certification of deck officers, marine engineers and radio- electronic officers, clustered under the EINAMAR (Escuela de Ingeniería Marina, Naútica y Radioelectrónica) umbrella.

These degrees are designed to provide the students not only with the proper academic certificate but also with a fully worldwide recognized professional certificate.

This is the reason why the studies not only have to fully fulfill the academic quality requirements laid down by ANECA (Agencia Nacional de Evaluación de la Calidad y Acreditación) or DEVA (Dirección de Evaluación y Acreditación - Agencia Andaluza del Conocimiento-) but also with the standard qualifications set up by the International Convention on Standard of Training, Certification and Watchkeeping (STCW 95) for seafarers as amended in 2010 (Manila Amendments).

According to this, as far as the students finish successfully their studies, and after an onboard training period, they will be able to obtain both, the academic and the professional certificates.

"Maritime Safety" is a one of the core subjects for these three programs and it has been designed as a transversal subject in such a way that all the students have the same contents and schedule. This subject aims to provide the students with the theoretical and practical training to cope with any situation involving fire prevention and firefighting as well as incident and accident prevention and resolution on board. It also introduces student into the world of contingency planning and evacuation procedures on board, the knowledge of how to use survival crafts and equipment to increase probabilities of survival when abandoning the ship, and the most appropriate techniques and procedures when abandoning the ship and boarding the survival crafts.
\end{abstract}

The main aim of the practical part of the subject is to improve the on board safety and risk awareness and to let the students get used to the most appropriate techniques and procedures as well as the use and maintenance of the protective equipment available on board.

To achieve this goal, problem based learning techniques related to real situations on board have been applied.

One of the specific practical workshop that have been implemented during the course, deals with the student training level in the use of SCBA (Self-contained breathing apparatus) and other protective equipment as well as orientation and search and rescue techniques within hostile environments with sensorial losses. As these situations can arise on board students must be familiar with them in order to properly face them.

The aim of this specific workshop is not only to improve the students' safety and risk awareness but also to encourage, strengthen and increase other professional and social skills.

Keywords: Orientation, rescue, maritime safety, practical workshops, team working.

\section{INTRODUCTION}

The European Higher Education Area (EHEA), which was created by the Budapest-Vienna Declaration of March, 2010, is the framework chosen by more than 45 countries (most of them integrated in the European Union) in order to lay down the convergence criteria in higher education. Its 
main objective is to ensure more comparable, compatible and coherent systems on higher education in Europe.

The new educational paradigm is focused in an active education which emphasizes the student involvement in the teaching/learning process rather than keeping the excessively theoretical existing model [1]

Information and Communication Technologies (ICT) use has been widely spread, and new educational methodologies as Problem Based Learning and Project Based learning, among other, have arisen in new pedagogical scenarios which improve the students' commitment with the learning process and support their critical thought as well as promote autonomous and co-operative learning encouraging the development of work groups [2].

To achieve the challenges posed by this new educational framework, Spanish universities have assumed significant educational and structural changes. Not only academic plans and syllabus but also learning and teaching methodologies and strategies have been modified.

Nautical higher education institutions in Spain, which were integrated into Spanish universities in 1988 [3], have also been involved in this process. According to this new paradigm, since 2010 the University of Cádiz offers three new degree programs related to merchant marine officers studies which are designed to ensure the proper training and certification of deck officers, marine engineers and radioelectronic officers, clustered under the EINAMAR (Escuela de Ingeniería Marina, Naútica y Radioelectrónica) umbrella.

The syllabuses of these degrees were designed to provide the students not only with the proper academic certificate but also with a fully worldwide recognized professional certificate. According to this, as far as students finish successfully their studies, and after an onboard training period, they will be able to obtain both, the academic and the professional certificates.

Because of this reason, the studies not only fully fulfil the academic quality requirements laid down by ANECA or DEVA (Dirección de Evaluación y Acreditación - Agencia andaluza del conocimiento - ) but also with the standard qualifications set up by the International Convention on Standard of Training, Certification and Watchkeeping (STCW 95) for seafarers as amended in 2010 (Manila Amendments). This Convention was adopted by IMO (International Maritime Organization) in 1978 and entered into force in Spain in 1984 [4] [5] [6].

\subsection{Problem Based Learning (PBL)}

Problem Based Learning (PBL) is a student-centered teaching-learning methodology [7] [8] [9] in which students are due to learn about the specific subject through the experience of solving an openended problem related with real situations.

According to this method, students are due to solve an open-ended problem previously introduced by the teacher to the whole group. Once the proposed situation is introduced, the students, working in smaller groups have to find out their own way to approach it. So, they have to analyse the problem and identify, not only what information do they already have, but also how, when and where can they access to the missed information that may lead to the resolution of the problem.

In such a situation, the role of the teacher is to support and guide the students through the teaching learning process, monitoring it and building up their own confidence. In addition teachers must encourage the students to develop their critical thinking, effective problem solving skills, self-directed learning and effective teamwork and collaboration capabilities.

In this way the students get a more personal and deeper involvement in the teaching-learning process, managing the entire process since the very beginning. This process will focus on the problem analysis, identification of learning needs, the search for documentary sources to meet them, the application of such knowledge to solving the problem and evaluating the results.

In this environment, students are the main character of whole the process, while teachers become a guide which support them going through it, encouraging their analytical and critical thinking through appropriate contributions [7].

Other of the most relevant element of this active learning method is the assessment process. Assessment becomes part of the learning process. The evaluating method should be designed in such a way that the students become responsible for assessing their own learning process, training, skills 
and acquired competencies. This requires a methodology in which self-assessment by the student, peer evaluation between students and teacher evaluation are included.

\subsection{Maritime Safety. A cross-cutting subject in higher maritime education}

Maritime Safety is a core subject in the syllabus of the three programs above mentioned. It has been designed as a cross-cutting subject in such a way that all the students have the same syllabus. According with STCW Convention, it is due to provide the students with the theoretical and practical training to cope with any safety related situation involving fire prevention and firefighting as well as incident and accident prevention and resolution on board. It also introduces student into the world of aboard contingency planning and evacuation procedures. In addition the students will learn of how to use survival crafts and equipment to increase probabilities of survival when abandoning the ship, and the most appropriate techniques and procedures when abandoning the ship and boarding the survival crafts.

To provide the students with the required knowledge, the subject is divided into a theoretical part and a practical part. While the main goal of the theoretical part is to provide students with the theoretical background that could allow them understand the technical and social phenomena which arise during an emergency situation on board a ship, the practical part of the subject is due to improve the on board safety and risk awareness and to let the students get used to the most appropriate safety techniques and procedures as well as the use and maintenance of the protective equipment available on board.

The practical workshops included in Maritime Safety curricula are compulsory for all the students despite their specialty and are to be assessed together with other safety related practical works. They account for $30 \%$ of the subject final score.

Since the introduction of the subject in the Merchant Marine degrees syllabus offered by Cádiz University in 2011, 303 students enrolled Maritime Safety courses (Fig.1). According to the figures of subsequent academic to years the number of students enrolled in this subject has increase.

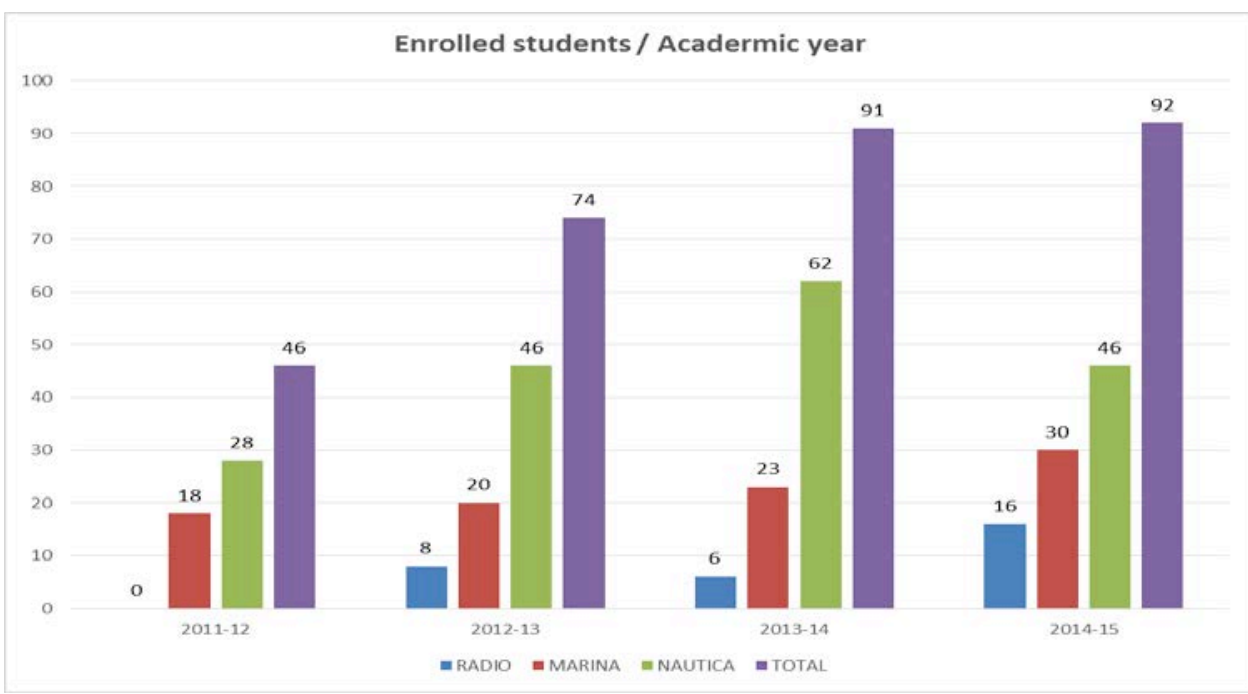

Fig 1. Number of enrolled students per academic year

On the other hand, fig. 2 and fig. 3 show the performance of students, both for all the students and according to each of the specialties.

Students' performance may not be considered bad because the low number of failing grades and dropouts. However, a significant lack of personal commitment with both the learning process and the acquisition of relevant skills have been detected. In order to improve the students' personal involvement, the faculty members responsible for the subject have decided to introduce a number of changes in structure of the course.

To achieve these goals, problem based learning techniques have been applied based on real situations that could arise on board of any merchant vessel. To cope with the proposed situations, the students have been divided into smaller groups composed of men and women of all the three 
degrees, and they have to put into practice the most appropriate techniques and procedures according with each one of the scenarios proposed.

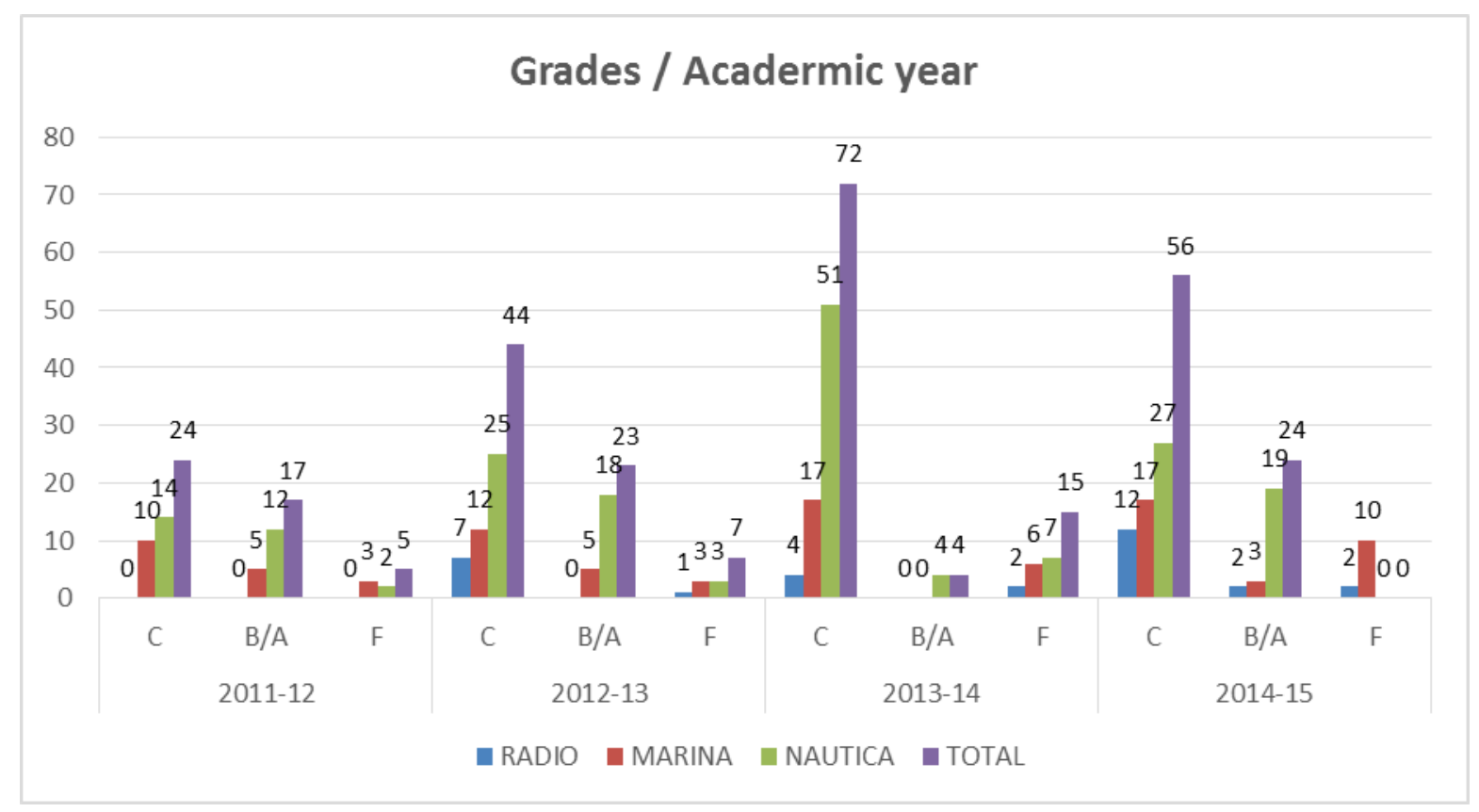

Fig. 2.- Grades obtained by students per academic year.

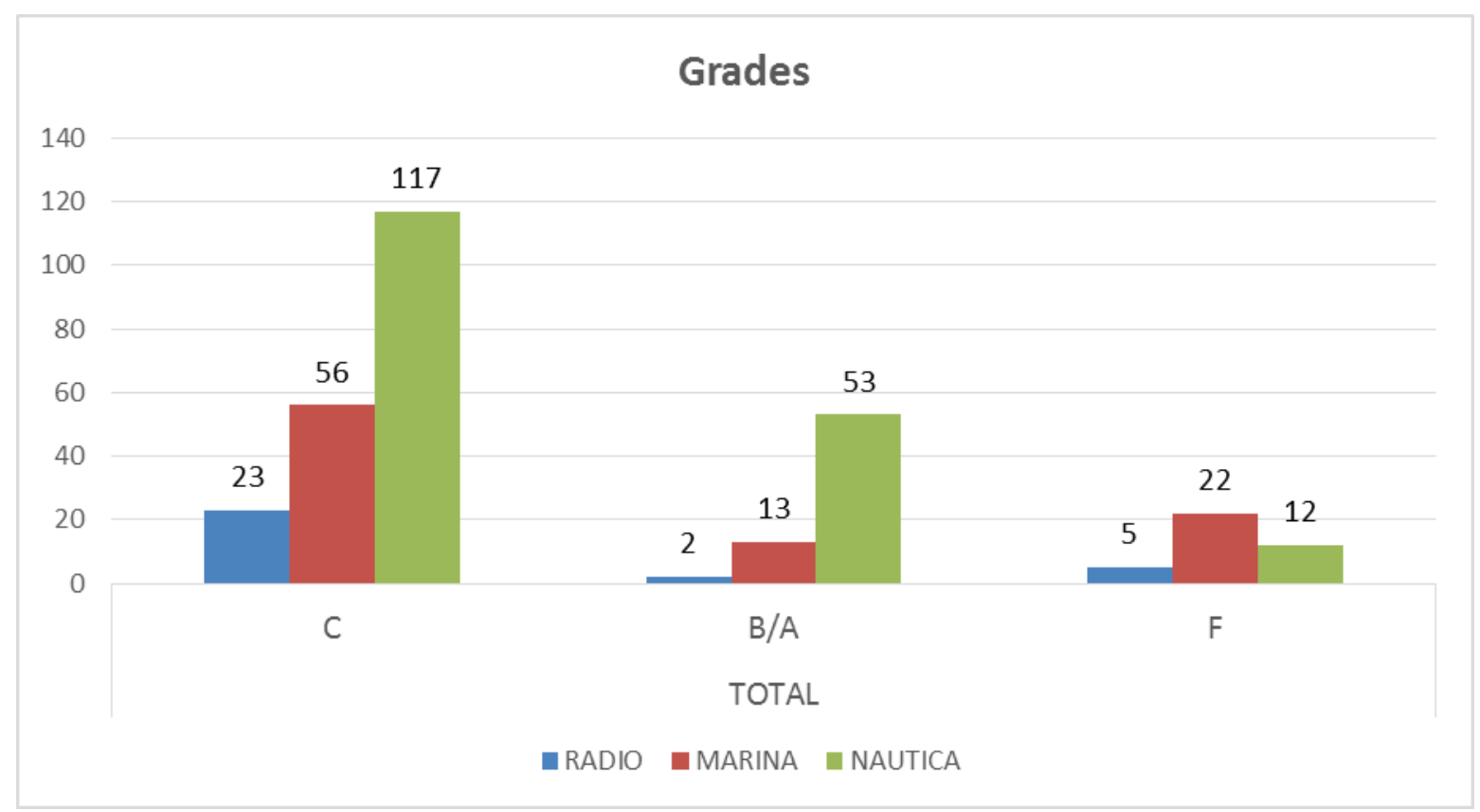

Fig.3. Grades obtained per students. Years 2011-2014

One of the specific practical workshop that have been implemented during the course, deals with the capability of the students of finding their position and perform search and rescue operations within an hostile environment with sensorial losses. These situations can arise on board so students must be familiar with in order to properly face them.

The aim of this specific workshop is not only to improve the students' safety and risk awareness but also to encourage, strengthen and increase: 
- The student training level in the use of SCBA (Self-contained breathing apparatus) and other protective equipment as well as orientation and search and rescue techniques within hostile environments with the loss of senses

- Emergency communications skills

- The self-confidence level of the students when coping with emergencies.

- The students' self-capabilities awareness.

- The students' ability to work in groups

- The students' awareness of the importance of been able to rely on the teamwork as a completely harmonized action.

In addition, media and audiovisual technologies are used to:

- Checking the progress of the students' learning process while performing the workshops

- Produce new teaching materials and the use of new media to strengthen the safety culture among students.

- Learn from the team's performance using "debriefing sessions" supported by audiovisual materials recorded during the practical workshops. This is considered a valuable tool for learning and continuous improvement.

\section{METHODOLOGY}

As noted above, the main motivation which has guided us in implementing these changes is to increase the degree of personal involvement of students in the learning process (reference). In addition, it is intended the student, highlighting their individual and collective capacities, improve their abilities to acquire in an autonomous way the tools and strategies required to critically analyze the problems that may arise during their professional development in real life (reference) providing a proper solution.

For this reason we have chosen to implement a limited PBL (Problem Based Learning) model adapted to our working environment in the field of maritime safety practices.

The model is to be implemented in the second half of the second quarter, during the development of the practical sessions related to guidance in hostile environments using computers.

As in the case presented by Garcia-Sevilla and others, we have decided to start the course in a conventional way, with the purpose of, on the one hand, ensure that students acquire the basic knowledge and skills to ensure their personal and group safety and, in the other hand that the transition to the PBL will be as easy as possible.

\subsection{The baseline}

During the previous years, the course was structured according to the following scheme:

- Classroom theoretical lessons.- Classroom lessons aimed at a single group of 80 or 90 students. In these classes, the teacher presents the material clearly structured as possible, supported by slides, video clips and real-life examples. Active participation of students is encouraged.

- Seminars.- With the same structure of the classroom lectures, they are aimed at groups of 30 to 50 students. They are focused on specific topics. Active participation of students is encouraged.

- Practical sessions. They are concentrated in the last weeks of the term. They are intensive eight to ten-hour sessions. They are aimed at groups of about 20 students. In these practical sessions, students, after a reminder about the use of safety equipment and different strategies and operational procedures should implement the knowledge acquired in several proposed scenarios.

In addition, to improve their training level and social and academic skills, students, divided into groups of 5 or 6 individuals, should perform several exercises proposed by the teachers. These exercises are performed both during the classroom lessons and outside of class. Students can access both personal and group guidance from the teachers either in face to face or through the virtual campus. 


\subsection{The methodological proposal}

In our case, it was considered the implementation ABP $4 \times 4$ model proposed by Prieto (10) adapted to our working environment.

As result of the adaptation process, the model finally implemented comprised seven steps grouped into 4 main phases.

In addition, a preliminary session is scheduled ant the begging of term in order to introduce the students the PBL methodology.

\subsubsection{Competences}

The first step taken while implementing the project was to determine the skills we intended that students acquire. Finally we decided that these should be both professional and social.

Professional Skills: the use of SCBA and other protective equipment as well as orientation and search and rescue techniques within hostile environments and emergency communications procedures.

Social skills: analytical skills, critical thinking skills, adaptability to different roles, team working ability

\subsubsection{The problem}

The problem proposed will be related to critical situation related to maritime safety that may arise on board.

The ultimate goal will be unique but there will be different ways to approach and achieve it.

It will allow students to apply the acquired knowledge and skills.

\subsubsection{The groups}

Considering the number of students enrolled in previous years, the total number of students should be divided into groups of 5 or 6 individuals [9] [11] [12].

Each group will be led by one of the students chosen by the group components.

The groups will be composed of students, both men and women, of the three specialties.

The groups have to be as heterogeneous as possible in order that the students become used to team working under unfavourable conditions.

\subsubsection{Schedule}

While face to face class sessions, they will be carried out according to subject schedule.

While individual and team working sessions, they will be carried out either during the regular subject schedule in non-school hours.

Both, results sharing and assessment sessions will be carried out according to schedule.

\subsection{Methodological development}

As indicated above, the proposed methodology divides the process into seven steps grouped into four main stages [13] [14]. In these the four stages, the students are due to work in five different scenarios:

- The whole class. This is the scenario chosen to introduce the methodology and to explain and discuss the results.

- Individual non-tutored research.

- Autonomous non-tutored team working research.

- Group tutorials

- Group practical session

\subsubsection{Preliminary session.}

As the students enrolled in Maritime Safety are not used to PBL methodology, it has become necessary to schedule a preliminary session at the begging of the second term. In this session students will be introduced into the PBL method and will be encouraged to assume their 
responsibilities within the learning process. They will also be encouraged to ask for any doubt that could arise related the learning method.

In this session the schedule for the whole process will be appointed by the teachers.

At the end of the session the whole class will be divided into small groups of 5 to 6 individuals the leader of each group will be elected.

Finally the whole group will be convened for a plenary session in about a week time.

\subsubsection{Phase 1.}

During phase 1, which groups the first five steps of Maastrich model [14] the "real life" problem proposed is introduced the the students. This will be the baseline of the PBL experience.

This will be done during the plenary session. In this session al groups will be provided with a written description of the context and the problem they have to cope with.

Students are required to read carefully the text and to ask anything they do not understand in order to avoid misunderstandings.

Once the plenary session will have ended, students, working within the group framework, must focus in the problem and deeply analyse it in order to assess the scope of the issue and the resources they will require to solve it. Activating their critical thinking, sharing their knowledge and ideas, students should be able to identify which of the required resources like equipment, knowledge, training, strategies or procedures have been already acquired and which ones are to be acquired.

In this stage the group leader distributes and coordinates the work among the other members.

\subsubsection{Phase 2.}

In phase number 2, students are due to research by themselves according with the planning settled down by the leader, which is also the link between the group and the teacher. Once each students have accomplished their duties they should share and discuss the results in order to build up the proper strategies and procedures to cope with the proposed situation.

\subsubsection{Face to face tutorial 1.}

While phase 2 is in progress and once students have fulfilled the requirements established by the teacher, which mainly is to build up a proper approach to the problem, a face to face group tutorial must be requested. During this tutorial, all the doubts that arose while sharing and discussing ideas and strategies will be solved and guidance to manage the proposed situation will be given by the teachers.

\subsubsection{Phase 3.}

Following this tutorial, the group must decide the final approach to solve the problem and communicate it to the teachers.

In case it would be considered an acceptable solution the group will be schedule for the practical session.

Practical sessions, which will take about 60 minutes considering both, preparation and resolution of the situation, will always be carried out under the supervision of the teachers in order to ensure the students personal safety and to avoid any unsafety or dangerous action.

According to those premises, the group will put into practice their own strategies and procedures using the appropriate safety equipment.

The whole session will be recorded and the records will be used for assessment purposes

\subsubsection{Phase 4.}

During phase 4 assessments will be carried out both by the teachers and the students.

An assessment plenary session will be convened and all the groups and the students as well as the learning process will be assessed. 
The assessment process comprised three stages: a self-assessment for both, each student and each group, a peer assessment among the groups so each group has to assess the other groups' performance and, finally, the students and groups performance assessed by the teachers.

The assessments will be based on the he practical sessions records which will be played during the plenary session.

In addition the whole process itself will be assessed by both teachers and students.

\section{RESULTS AND CONCLUSION}

Although the process of adoption of PBL methodology in the maritime safety course is not fully implemented and therefore are not yet produced results, according Vizarro improvements in significant aspects of the learning process could be expected in relation to the objectives proposed, which were, primarily, to increase the level of student commitment with the learning process and the acquisition of specific professional skills.

However, as Garcia-Sevilla indicates, to enable students to acquire skills more effectively the, it is necessary to raise a continued use of this method of learning.

Therefore we pretend that this pilot project will be use as a starting point for the widespread use of this teaching methodology, with the necessary adaptations, to the whole subject and promote a joint use with other related subjects in the field of maritime safety.

\section{REFERENCES}

[1] Espinosa J. K., Jiménez, J., Olabe, M. A. and Basogain, X. (2006). Innovación Docente para el Desarrollo de Competencias en el EEES. Tecnologías aplicadas a la enseñanza de la Electrónica. Congreso Tecnologías Aplicadas a la Enseñanza de la Electrónica (TAEE 2006).

[2] Coll, C., Rochera, M.J., Mayordomo, R.M. and Naranjo, M. (2007). Continuous Assessment And Support For Learning: An Experience In Educational Innovation With ICT Support In Higher Education. Electronic Journal of Research in Educational Psychology, Vol 5 (3), ISSN 1696295, pp 783-804.

[3] BOE, Boletín Oficial del Estado (1988). Real Decreto 1522/1988, de 2 de diciembre, sobre integración de las Enseñanzas Superiores de la Marina Civil en la Universidad. BOE núm. 304, de 20 de diciembre de 1988, pp. 35647-35648.

[4] BOE, Boletín Oficial del Estado (1984). Instrumento de adhesión de 11 de octubre de 1984 de España al Convenio Internacional sobre normas de Formación, Titulación y Guardia para la Gente del Mar, 1978, hecho en Londres el 7 de julio de 1978.. BOE Núm. 267 de 7 de noviembre de 1984, Sec. I., pp. 32074-32116

[5] BOE, Boletín Oficial del Estado (2012). Enmiendas de Manila de 2010 al Código de formación, titulación y guardia para la gente de mar (Código de formación) Resolución 2 de la Conferencia de las Partes en el Convenio Internacional sobre normas de formación, titulación y guardia para la gente de mar (Convenio de formación) 1978, aprobadas en Manila el 25 de junio de 2010. BOE núm. 133, de 4 de junio de 2012, páginas 39851 a 40248.

[6] Yabuki, H. (2011). 'The 2010 Manila Amendments to the STCW Convention and Code and changes in Maritime Education and Training', Journal of Maritime Researches Vol, 1(1), pp.1117, 2010.

[7] BARROWS, H.S. (1986). A Taxonomy of problem-based learning methods, en Medical Education, 20/6, 481-486.

[8] Wilkerson, I. (1996). "Tutors and small groups in problem-based learning: Lessons from the literature." In L. Wilkerson \& W. H. Gijselaers (Eds.). Bringing problem-based learning to higher education: Theory and practice (pp. 23-32).

[9] EXLEY, K. Y DENNIS, R. (2007). Enseñanza en pequeños grupos en Educación Superior. Madrid: Narcea.

[10] Prieto, A., Barbarroja, J., Reyes, E., Monserrat, J., Diaz, D., Villarroel, M. y Álvarez, M. (2006a). Un nuevo modelo de aprendizaje basado en problemas, el ABP $4 \times 4$, es eficaz para desarrollar 
competencias profesionales valiosas en asignaturas con más de 100 alumnos. Aula abierta 87, 171-194.

[11] MORALES, P. Y LANDA, V. (2004). Aprendizaje basado en problemas, en Theoria, Vol.13. Págs. 145-157.[Disponible en http://redalyc.uaemex.mx/redalyc/pdf/299/29901314.pdf]

[12] DE MIGUEL, M. (coord.). Metodologías de enseñanza para el desarrollo de competencias. Orientaciones para el profesorado universitario ante el Espacio Europeo de Educación Superior. Madrid: Alianza..

[13] Moust, J.H.C., Bouhuijs, P.A.J. y Schmidt, H.G. (2007). El aprendizaje basado en problemas: Guía del estudiante. Cuenca: Ediciones de la UCLM

[14] Schmidt, H.G. (1983). Problem-based learning: rationale and description. Medical Education 17, 11-16. 